九州大学学術情報リポジトリ

Kyushu University Institutional Repository

Isolation of New Bacillus thuringiensis Strains with Insecticidal Activities Against Diptera Insect Pests and Their Biological Characteristics

HUR, Young A

Department of Applied Biology, College of Agriculture and Life Sciences, Chungnam National University

LEE, You Kyoung

Department of Applied Biology, College of Agriculture and Life Sciences, Chungnam National University

KIM, Hee Ji

Department of Applied Biology, College of Agriculture and Life Sciences, Chungnam National University

YOUN, Young Nam

Department of Applied Biology, College of Agriculture and Life Sciences, Chungnam National University

他

https://doi.org/10.5109/2340913

出版情報: 九州大学大学院農学研究院紀要. 64 (2)，pp.257-266，2019-09-02. Faculty of Agriculture, Kyushu University

バージョン :

権利関係: 


\title{
Isolation of New Bacillus thuringiensis Strains with Insecticidal Activities Against Diptera Insect Pests and Their Biological Characteristics
}

\author{
Young A HUR ${ }^{1}$, You Kyoung LEE ${ }^{1}$, Hee Ji KIM${ }^{1}$, Young Nam YOUN ${ }^{1}$, \\ Chisa YASUNAGA-AOKI ${ }^{2 *}$ and Yong Man YU ${ }^{1 *}$
}

\author{
Laboratory of Insect Pathology and Microbial Control, Institute of Biological Control, \\ Faculty of Agriculture, Kyushu University, Fukuoka 819-0395, Japan \\ (Received May 7, 2019 and accepted May 8, 2019)
}

\begin{abstract}
Although chemical insecticides have been used to control Diptera agricultural pests, because of characteristics of the pests that invade into soil or into the roots of plants to do harm over most of their larva developmental period, it is difficult to effectively control the pests using chemical insecticides, and biological control methods are necessary due to increases in the production of eco-friendly agricultural products. Therefore, this study conducted the survay of new control agent. In order to isolate Bacillus thuringiensis strains that show insecticidal activities against Diptera, B. thuringiensis strains were selected from soils from the streams in Yangyang, Gangwon Province, Saryang-do, Chuja-do, and Jeju-do (islands), which are main habitats of Diptera. In bioassays, isolate S11 and C55 showed high insecticidal activities not lower than 90\% in both Lycoriella ingenua and Aedes albopictus larvae, and the selected strain S11 showed insecticidal activities not lower than 50\% in Bradysia agrestis. In investigation of the insecticidal activities against $L$. ingenua larvae, strains S11 and C55 showed higher insecticidal activities than the control strain B. thuringiensis subsp. Israelensis which is widely used as a pesticide against Diptera. SDS-PAGE was performed to compare the $\delta$-endotoxin protein characteristics of the two selected strains. Strain S11 showed three main bands at $150 \mathrm{kDa}, 75 \mathrm{kDa}$, and $65 \mathrm{kDa}$, while strain $\mathrm{C} 55$ showed three main bands at $150 \mathrm{kDa}, 70 \mathrm{kDa}$, and $25 \mathrm{kDa}$. In the digestion reactions with $L$. ingenua triturated solution, the strain $\mathrm{S} 11$ was digested to $75 \mathrm{kDa}$ and $25 \mathrm{kDa}$ to show bands while strain C55 showed a band at $25 \mathrm{kDa}$. The results of PCR of cry genes of the two strains indicated that both strains have cyt2Aa genes. In the plasmid DNA patterns, S11 showed a total of six bands and C55 showed a total of two bands.
\end{abstract}

Key words: Bacillus thuringiensis, Biological activity, Diptera, Isolation

\section{INTRODUCTION}

Recently, various pathogens and insect pests have occurred in main fruit and vegetable growing regions in South Korea because optimum conditions for the survival of pathogens and insect pests have been formed in those regions. It has been reported that Diptera insect pests, which are important among diverse agricultural pests occurring in South Korea, are also widely distributed throughout the world (Jagdale et al., 2007; Vaughan et al., 2011). Lycoriella ingenua and Bradysia agrestis that belong to Diptera and Sciaridae, respectively, are known to be representative agricultural pests that cause severe economic damage because their larvae directly do harm to crops during their feeding activities (Shamshad, 2010). L. ingenua is an insect pest that does harm to mushrooms such as button mushrooms, oyster mushrooms, and shiitake mushrooms. It directly feeds on mushroom mycelia and does harm to fruiting bodies thereby reducing mushroom yields to cause damage to farmers (Erler et al., 2011; Kim et al., 2012). B. agrestis occurs in humid environments in

1 Department of Applied Biology, College of Agriculture and Life Sciences, Chungnam National University, Daejon 305-764, Korea

2 Laboratory of Insect Pathology and Microbial Control, Institute of Biological Control, Faculty of Agriculture, Kyushu University, Fukuoka 819-0395, Japan

* Joint corresponding authors (E-mail: ymyu@cnu.ac.kr and yasunaga@grt.kyushu-u.ac.jp) temperate and tropical regions or in environments rich in organic matter in soil and does harm to the roots of fruits and vegetables such as onions, peppers, tomatoes, lettuce, and mushrooms to interfere with the growth and causes damage to crops with secondary infections by plant pathogens (Chambers et al., 1993; Cloyd, 2000).

Although chemical insecticides have been used to control L. ingenua and B. agrestis at domestic agricultural sites, effective control is difficult. The agricultural chemicals registered for $L$. ingenua should be applied after mushroom seeding or before and after covering up the seeds with soil and the agricultural pesticides applied at those times do not affect the insect pests. Since the use of agricultural chemicals in the early stage of the occurrence of insect pests is restricted due to the problem of pesticides residue, there are difficulties in controlling $L$. ingenua that occurs throughout the entire mushroom cultivation period (Lee et al., 2015a; Yoon et al., 2016). Meanwhile, difficulties in controlling $B$. agrestis come from the fact that $B$. agrestis larvae are present in soil during most of their developmental period before they become imagoes to do harm to the roots of plant bodies or invade inside the tissues of roots to do harm to the roots (Jeon et al., 2007). Although there are insecticides registered as agricultural chemicals such as teflubenzuron flowable, chlorphenapyr flowable, and acetamiprid wettable powder (KCPA, 2017), biological control methods are necessary due the issues such as the safety of agricultural products and environmental pollution. 
Bacillus thuringiensis is the most frequently used as a biological control agent. B. thuringiensis is an insect pathogenic Gram-positive aerobacillus and it is one of the important microorganisms used in biotic pesticides because it forms parasporal inclusions (Li and Bouwer, 2014; El Khoury et al., 2014). B. thuringiensis, an insect pathogenic bacterium, was first isolated from the body of diseased silkworm larvae in 1901 and identified to show high insecticidal activities in Lepidopteran larvae (Jin et al., 2009) and thereafter, in 1977 when B. thuringiensis subsp. israelensis was found, $B$. thuringiensis was reported to show insecticidal activities not only in Lepidoptera but also in Diptera (Goldberg and Margalit, 1997). As a subspecies of $B$. thuringiensis that shows high insecticidal activities in Diptera, B. thuringiensis subsp. israelensis (Balaraman et al., 1981; Shim et al., 1990; AbdelHameed et al., 1990), which shows high insecticidal activities in mosquitoes that are Diptera hygiene insect pests, was found (Balaraman et al., 1981; Shim et al., 1990; Abdel-Hameed et al., 1990). Thereafter, B. thuringiensis subsp. Morrisoni (Padua et al., 1984), B. thuringiensis subsp. Medellin (Orduz et al., 1992), etc. were isolated in various areas in the world but most of them were reported to have low toxicity to Diptera insect pests (Ishii and Ohba, 1993). Therefore, new $B$. thuringiensis species that show toxicity to Diptera insect pests should be isolated and their potential as biotic pesticides should be reviewed.

In this study, Gangwon-do, Chuja-do, Saryangdo, and Jeju-do were selected as these areas were expected to be habitats of Diptera insect pests because natural environments are well maintained, temperatures and humidity are high, and large amounts of organic matter exist in these areas. B. thuringiensis strains were isolated and identified from the soils obtained in these areas, strains with excellent activity were selected, and the strains' biological characteristics were studied to identify the strains' morphological characteristics and

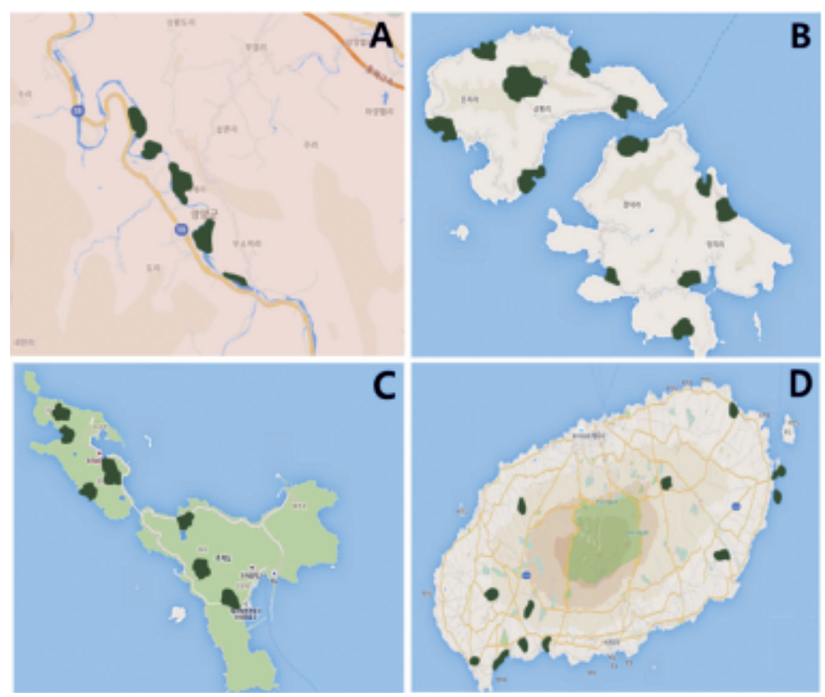

Fig. 1. Map of the locations in Korea where samples were collected for isolation of B. thuringiensis (areas in black). A Gangwondo yangyang-namdaecheon; B: Saryang Island; C: Chuja Island; D: Jeju Island. insecticidal activities, the characteristics of the insecticidal proteins of the strains, and plasmid DNA patterns of the strains.

\section{MATERIALS AND METHODS}

\section{Soil sampling}

Soil samples were collected from various areas in Yangyang, Gangwon Province, Saryang-do (island), Chuja-do (island), and Jeju-do (island) (Fig. 1). A total of 477 soil samples were collected; 130 from Namdaecheon region in Yangyang, Gangwon Province, 94 from areas in Saryang-do, 131 from areas in Chujado, and 122 from areas in Jeju-do. As for the soil sampling method, $10 \mathrm{~g}$ each of soil at $10 \mathrm{~cm}$ depth from the surface of the earth was collected from each area using a sterilized reagent spoon. The collected samples were put into sterilized containers and the containers were sealed and stored at $4^{\circ} \mathrm{C}$ until the samples were used.

\section{Isolation and morphological observation of $B$. thuringiensis strains}

Bacillus strains were isolated using the method of Ohba and Aizawa (1978). $1 \mathrm{~g}$ of the collected soil and $10 \mathrm{ml}$ of sterilized water were put into a test tube and stirred. In order to selectively remove those germs that form only nutrient cells and cannot form spores, the samples were heat treated in a constant-temperature water bath at $60^{\circ} \mathrm{C}$ for 30 minutes. After the heat treatment, the soil was allowed to settle, and the supernatant was diluted to $10^{-3}$ and was evenly spread on a nutrient agar plate with an inner diameter of $90 \mathrm{~mm}$. The plate after spreading were cultured for $3-4$ days at a $27^{\circ} \mathrm{C}$ incubator and colonies similar to $B$. thuringiensis strains were selected from among colonies formed. The selected colonies were streak-spread on an NA medium and cultured at $27^{\circ} \mathrm{C}$ for 4 to 5 days. Thereafter, the morphology of the $\delta$-endotoxin protein crystals was checked with a phase contrast microscope of 1,000 magnifications. Strains in which $\delta$-endotoxin protein crystals were identified were diluted in sterilized water, $2 \mathrm{ml}$ each of the strain solution was spread on a $150-\mathrm{mm}$ Nutrient agar plate, and the plate was incubated at $27^{\circ} \mathrm{C}$ for 5 days. After identifying that autolysis occurred, the strain solution was centrifuged for 14 minutes at $15,000 \mathrm{rpm}$ with a centrifugal separator (Avanti JE, Beckman), and the bacilli were collected and used in biotic assays. For comparison of insecticidal activities, B. thuringiensis subsp. israelensis strain, widely known as a Diptera control agent was selected as a control strain.

\section{Test insect}

The diamondback moth (Plutella xylostella), a Lepidopteran insect pest used in this experiment, was bred for successive generations with young radishes as a host in the biotic insect pest control laboratory at Chungnam National University. Spodeoptera litura and Spodoptera exigua were bought from the National Institute of Agricultural Sciences of the Rural 
Development Administration and those that were bred for successive generations using artificial feed were used. The imagoes were supplied with $10 \%$ sugar water as a feed. The $B$. agrestis, Diptera, used in this experiment was those that were bred for successive generations in the biotic insect pest control laboratory at Chungnam National University and the L. ingenua used in this experiment was those collected from a button mushroom farm located in Songgu-ri, Chochon-myeon, Buyeo-gun, Chungcheongnam Province and bred for successive generations. Aedes albopictus was purchased from the Insect Physiology Laboratory of Chungnam National University and those that were bred using fry feed were used. All insects were bred under at temperatures of $25 \pm 1^{\circ} \mathrm{C}$, a light condition of $16 \mathrm{~L}: 8 \mathrm{D}$, relative humidity of $50-60 \%$.

\section{Bioactivity assay}

The bioactivity of diamondback moth (P. xylostella) was tested using the leaf dipping method (Tabashnik et al., 1990) with some modification. Cabbage leaves cut to $5 \mathrm{~cm} \times 5 \mathrm{~cm}$ were dipped in $30 \mathrm{ml}$ of $B$. thuringiensis diluted solution and dried thereafter at room temperature. Three repetitions of 10 third-instar larvae of diamondback moth (P. xylostella) were tested and the mortality was investigated for 72 hours. As for the bioactivity assay for $S$. exigua, artificial feed was cut to $1 \mathrm{~g}$ pieces and each piece was inoculated with $200 \mu \mathrm{l} \mathrm{B}$. thuringiensis strain diluted solution, dried at room temperature, put into a Petri dish, six repetitions of five third-instar $S$. exigua larvae were tested, and mortality was investigated for 120 hours.

As for the bioactivity assay for $L$. ingenua, $1 \mathrm{~g}$ of king oyster mushroom was inoculated with $200 \mu \mathrm{l}$ of $B$. thuringiensis strain diluted solution, dried at room temperature, and $10 \mathrm{~L}$. ingenua 4-5 days old after hatching were put into a petri dish. Three repetitions of this test were carried out and the mortality was investigated for 168 hours.

As for the bioactivity assay for $B$. agrestis, $1 \mathrm{~g}$ of potato was inoculated with $200 \mu \mathrm{l}$ of $B$. thuringiensis strain diluted solution, dried at room temperature, and 10 B. agrestis 3-4 days old after hatching were put into a petri dish. Three repetitions of this test were carried out and the mortality was investigated for 168 hours.

The biological activity assay A. albopictus was carried out using the experimental method of WHO (2005) with some modification. Ten larvae 3-4 days old after hatching were out into a $90 \mathrm{ml}$ plastic cup containing 30 $\mathrm{ml}$ of water and $300 \mu \mathrm{l}$ of $B$. thuringiensis strain diluted solution was put into the plastic cup. Three repetitions of this test were carried out and the mortality was investigated for 72 hours.

All experiments were carried out in three repetitions and the lethal concentration $\left(\mathrm{LC}_{50}\right.$ and $\left.\mathrm{LC}_{95}\right)$ was calculated with mortality rates obtained by investigating 5-7 ranges of concentrations from the concentration for deaths of all experimental larvae to the concentration for survival of all experimental larvae using the PC program based on Finney's (1971) probit calculation method
(Raymond, 1985).

\section{SDS-PAGE}

The selected $B$. thuringiensis strain was inoculated on a nutrient agar medium and incubated at $27^{\circ} \mathrm{C}$ for 5 days. After identifying that autolysis occurred with a phase contrast microscope, the cells were centrifuged at $15,000 \mathrm{rpm}$ and $4^{\circ} \mathrm{C}$ for 10 minutes using a PBS buffer. The supernatant was discarded and the remaining cells were washed three times with washing buffer I (500 mM $\mathrm{NaCl}, 2 \%$ Triton X-100) and twice with washing buffer II (500 $\mathrm{mM} \mathrm{NaCl})$. Sterilized water was added to the washed parasporal inclusions and kept at $-20^{\circ} \mathrm{C}$ until the parasporal inclusions were used (Lee et al., 2015b). The method of Laemmli (1970), was partially modified to use $12 \%$ separating gel and 5\% stacking gel. After electrophoresis, the gel was stained with $0.5 \%$ Coomassie brilliant blue.

The triturated larva solution to be used for the digestion reaction by the triturated larva solution experiment was prepared by knocking the larvae cold by placing them at $-20^{\circ} \mathrm{C}$ for 10 minutes, removing the attached limbs using a sterilized dissecting scissors, and disinfecting the surface of larva bodies, and triturating the larva bodies. The larva bodies were immersed in $1 \% \mathrm{NaClO}_{3}$ and $70 \%(\mathrm{w} / \mathrm{w})$ ethanol for one minute for surface disinfection and washed with sterilized saline solution (9.32 g $\mathrm{NaCl}, 0.77 \mathrm{~g} \mathrm{KCl}, 0.5 \mathrm{~g} \mathrm{CaCl}_{2}, 0.18 \mathrm{~g} \mathrm{NaHCO}_{3}, 0.01 \mathrm{~g}$ $\mathrm{NaH}_{2} \mathrm{PO}_{3}, 1$ l, pH7.4) to remove remaining ethanol. Thereafter, $200 \mu \mathrm{l}$ of sterilized water was put into a $1.5 \mathrm{ml}$ eppendorf tube, surface-disinfected larvae were put into the eppendorf tube one by one while triturating them with a sterilized insect trituration rod, the resultant triturated larva solution was centrifuged, and only the supernatant was taken. In the digestion reaction by triturated larva solution experiment, the insecticidal crystalline toxin protein was mixed with the triturated larva solution and the mixture was held for reaction at $37^{\circ} \mathrm{C}$ for 15 minutes. The protein dissolved by the triturated larva solution was identified through electrophoresis.

\section{PCR analysis}

Gene-specific primer sets were used to identify the Cry-type gene of $B$. thuringiensis strain $\delta$-endotoxin genes (Table 1). PCR amplification was performed using Thermal Cycle C1000 TM (BIO-RAD). The reaction solution was prepared by mixing $17 \mu \mathrm{l}$ of distilled water, $1.0 \mu \mathrm{l}$ of each primer set, and $1.0 \mu \mathrm{l}$ of template DNA into a premix (Bioneer) containing dNTP and a buffer component and adjusting the final volume to $20 \mu \mathrm{l}$. PCR was conducted under conditions consisting of 30 cycles for $5 \mathrm{~min}$ at $95^{\circ} \mathrm{C}, 1 \mathrm{~min}$ at $95^{\circ} \mathrm{C}$, annealing for $1 \mathrm{~min}$ at $60^{\circ} \mathrm{C}$ and for $5 \mathrm{~min}$ at $72^{\circ} \mathrm{C}$ to produce PCR product DNA. The product DNA produced as such was electrophoresed on $1.0 \%$ agarose gel.

\section{Plasmid DNA analysis}

Plasmid DNA extraction was experimented with the protocol of the Qiagen midi kit with some modification. 
Table 1. Crystal protein gene-specific primers for PCR analysis

\begin{tabular}{|c|c|c|}
\hline Cry genes & Primer sequences & PCR product (bp) \\
\hline \multirow{2}{*}{ cry1Aa } & 5’ GAGCCAAGCGACTGGAGCAGTTTACACC & 724 \\
\hline & 3’ ATCACTGAGTCGCTTCGCATGTTTGACTTTCTC & - \\
\hline \multirow{2}{*}{$\operatorname{cry} 1 \mathrm{Bc}$} & 5’ CAGAAACAACAGAACGACC & 921 \\
\hline & 3' САСТTCCCCACCATCCAT & - \\
\hline \multirow{2}{*}{ cry2A } & 5' CAGATACCCTTGCTGGTGTAA & 1073 \\
\hline & 3’ ATAGGCCCGTGCTCCACCAGG & - \\
\hline \multirow{2}{*}{ cry4Aa } & 5' CGAGGTGAAATTTGCTCC & 1951 \\
\hline & 3’ ATGGCTTGTTTCGCTACATC & - \\
\hline \multirow{2}{*}{ cry4Ba } & 5’ GGTGCTTCCTATTCTTTGGC & 347 \\
\hline & 3’ ATGGCTTGTTTCGCTACATC & - \\
\hline \multirow{2}{*}{ cry10Aa } & 5' ACGCAAATAAGCCAAATCAACC & 257 \\
\hline & 3' CCAAACATTTGCAGGGTCAG & - \\
\hline \multirow{2}{*}{ cry11Aa } & 5' TGCTGATAACAATGGCAATGAAA & 254 \\
\hline & 3’ TGGTGGTATTGTTCCGGTTC & - \\
\hline \multirow{2}{*}{ cry $11 \mathrm{Ba}$} & 5' GAATCAGCGCCTGAACAATG & 615 \\
\hline & 3' TAATGCGAGTTGCTGCGATA & - \\
\hline \multirow{2}{*}{ cry19A } & 5' GGGTCCTGGTCATACAGGTG & 664 \\
\hline & 3’ GCCATGCTTCACGTACATTG & - \\
\hline \multirow{2}{*}{ cry20A } & 5' CCAGGCGAGTCAGGATTAGA & 301 \\
\hline & 3’ CTTCTGAATCCACGGCTGTT & - \\
\hline \multirow{2}{*}{ cry $24 \mathrm{C}$} & 5' CTGCAGCAGCGATAACTTCA & 415 \\
\hline & 3' GCGGCTTGTGTAAAGGTAGG & - \\
\hline \multirow{2}{*}{ cry30A } & 5' AGCAAAACAGGCGGTAGATG & 523 \\
\hline & 3' TCGTACACGATCGCTTTCTG & - \\
\hline \multirow{2}{*}{ cyt1Aa } & 5' GATGGGTGCTGTAGTGAGTT & 221 \\
\hline & 3' TAGCAGTTTCCTTGCCCCA & - \\
\hline \multirow{2}{*}{ cyt2Aa } & 5' ACGGTTCCATCCAGTGATTTA & 494 \\
\hline & 3’ TCAACATCCACAGAAACCTCA & - \\
\hline \multirow{2}{*}{ cyt2Ba } & 5' GGCATATTGCATTAACAGTTCCA & 401 \\
\hline & 3’ AGCTGATAAATTACGCCAAACAA & - \\
\hline
\end{tabular}

The selected B. thuringiensis strain was inoculated into $10 \mathrm{ml}$ of Luria-Bertani medium (Difco, USA) and cultured at $220 \mathrm{rpm}$ at $30^{\circ} \mathrm{C}$ for $16-18$ hours. Thereafter, $1 \mathrm{ml}$ of the culture solution was inoculated into $100 \mathrm{ml}$ of SPY medium $\left(0.2 \% \quad\left(\mathrm{NH}_{4}\right)_{2} \mathrm{SO}_{4}, \quad 1.4 \% \quad \mathrm{~K}_{2} \mathrm{HPO}_{4}, \quad 0.6 \%\right.$ $\mathrm{KH}_{2} \mathrm{PO}_{4}, \quad 0.1 \%$ sodium citrate, $0.02 \% \quad \mathrm{MgSO}_{4} \cdot 7 \mathrm{H}_{2} \mathrm{O}$, 0.2 yeast extract, $0.1 \%$ glucose), cultured for 4 hours, and centrifuged at $7,000 \mathrm{rpm}$ at $4^{\circ} \mathrm{C}$ for 10 minutes. The supernatant was discarded, $200 \mu \mathrm{l}$ of lysozyme $(50 \mathrm{mg} /$ $\mathrm{ml})$ was added to $5 \mu \mathrm{l}$ of $\mathrm{P} 1$ buffer, and the pellet was dissolved, and cultured at $37^{\circ} \mathrm{C}$ for 1 hour and 30 minutes. Thereafter, $5 \mu \mathrm{l}$ of $\mathrm{P} 2$ buffer was added and mixed, and the mixture was centrifuged at $10,000 \mathrm{rpm}$ at $4^{\circ} \mathrm{C}$ for 10 minutes and $5 \mu \mathrm{l}$ of P3 buffer was added and centrifuged under the same conditions. After making $4 \mathrm{ml}$ of QBT buffer pass through the Qiagen tip, the centrifuged supernatant and $20 \mathrm{ml}$ of QC buffer were made to pass through the Qiagen tip in order of precedence. After completely passing the column, $5 \mathrm{ml}$ of $\mathrm{QF}$ buffer was added to dissolve and isolate the DNA. After adding
$3.5 \mathrm{ml}$ of isopropanol to the isolated DNA solution and dividing the solution into Eppendorf tubes, the solution was centrifuged at $15,000 \mathrm{rpm}$ at $4^{\circ} \mathrm{C}$ for 30 minutes. Thereafter, the supernatant was discarded, $1 \mathrm{ml}$ of $70 \%$ ethanol was added, and the mixture was centrifuged for 10 minutes under the same conditions. After discarding the supernatant and drying the solution on a clean bench, 30-50 $\mu \mathrm{l}$ of triple distilled water was added to dissolve the DNA. The dissolved DNA was put into sterilized Eppendorf tubes and stored at $-20^{\circ} \mathrm{C}$ until being used.

\section{RESULTS AND DISCUSSION}

\section{Isolation of $\boldsymbol{B}$. thuringiensis strains}

Studies on isolation, identification, and characterization of the strains of $B$. thuringiensis, an insect pathogenic bacterium, have been actively carried out in various countries around the world. B. thuringiensis has been isolated at high rates; about $24 \%$ from soil samples 
in Brazil (Bravo et al., 1998), about 60\% from soil samples in Colombia (Armengol et al., 2007), and about 23\% from soil samples in Spain (Quesada-Moraga et al., 2004). The differences as such seem to be attributable to the direct effects of differences in native microbes, $\mathrm{pH}$, humidity, and organic matter concentrations among individual countries on the life cycle of the B. thuringiensis strains (Argôlo-Filho and Loguercio, 2013). Those B. thuringiensis strains that produces $\delta$-endotoxin proteins were isolated at a rate of about $11 \%$, that is, from 53 out of a total of 477 soil samples collected from Namdaecheon (stream) in Yangyang, Gangwon Province, Saryang-do and Chuja-do, Jeju- do which are areas rich in natural resources and biodiversity (Table 2).

\section{Selection and morphological characteristics of $\boldsymbol{B}$. thuringiensis strains}

Among the 53 B. thuringiensis strains isolated, 13 were found to show at least 50\% insecticidal activities in Diptera or Lepidoptera (Table 3 ). The types of $\delta$-endotoxin proteins possessed by $B$. thuringiensis can be used as important information because they are related to the main insect orders that show insecticidal activi- ties. The types of $\delta$-endotoxin proteins in the 13 isolated B. thuringiensis strains were classified into 8 pyramidal types that show insecticidal activities in Lepidoptera and Diptera and 5 spherical types that show insecticidal activities in Diptera (Fig. 2).

\section{Test of biological activity of $B$. thuringiensis strains}

The 53 strains of $B$. thuringiensis isolated from soil were diluted to a concentration of $1.0 \times 10^{7}(\mathrm{cfu} / \mathrm{ml})$ each and their bioactivities in three Lepidoptera insect pest species, diamondback moth (P. xylostella), S. exigua, $S$. litura and three Diptera insect pest species, $L$. ingenua, B. agrestis and A. albopictus were tested in order to identify the host ranges of the strains. The results indicated that the strains that showed at least $50 \%$ insecticidal activities in Lepidoptera or Diptera were G53, S1, S2, S4, S6, S11, S43, C55, J9, J102, J114, J131, J145, J186, and J191, which are a total of 15 in number (Table 3 ). These results are similar to those reported for non-toxic strains that produce $\delta$-endotoxin proteins but do not exhibit toxicity, which were at a rate of about $30 \%$ of the isolated strains (Kim et al., 1995). Among the isolated strains, those strains that

Table 2. Number of isolated $B$. thuringiensis from soil at collecting areas

\begin{tabular}{ccc}
\hline Locality & $\begin{array}{c}\text { Number of soil sample } \\
\text { examined }\end{array}$ & $\begin{array}{c}\text { Number of soil sample with } \\
\text { B. thuringiensis isolated }\end{array}$ \\
\hline Yangyang-namdaecheon & 130 & 12 \\
Saryang island & 94 & 20 \\
Chuja island & 131 & 14 \\
Jeju island & 122 & 7 \\
\hline Total & 477 & 53
\end{tabular}
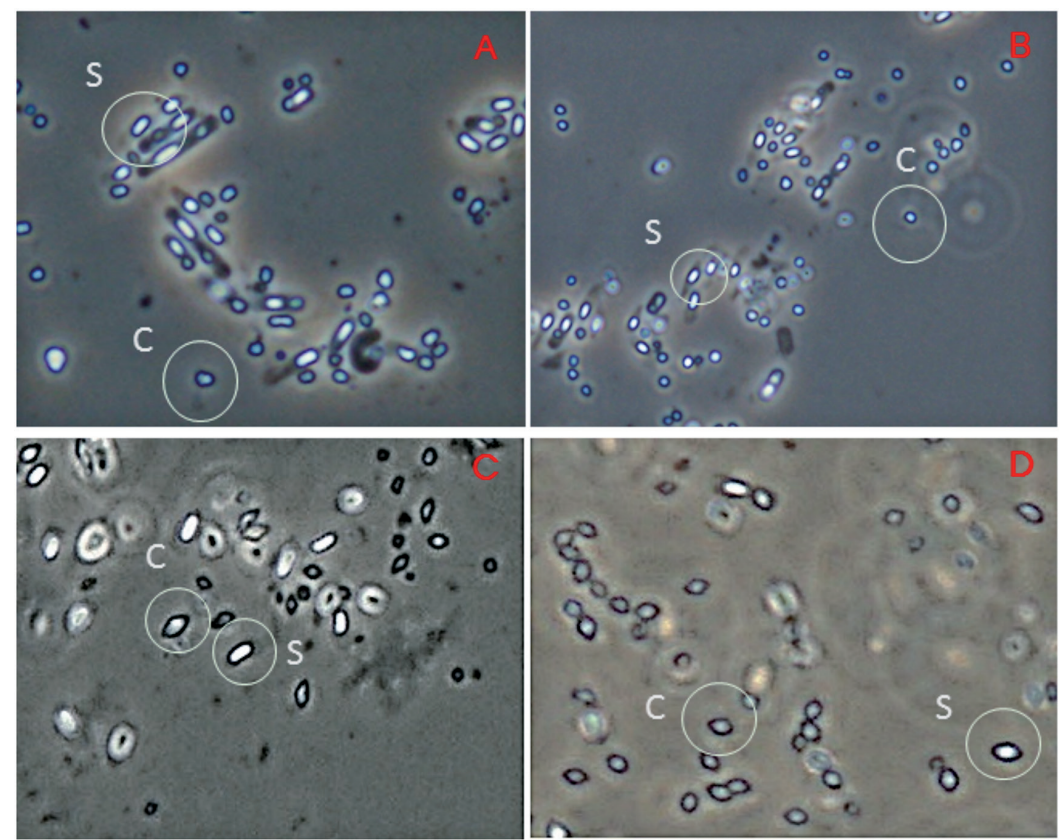

Fig. 2. Phase-contrast microscope photographs of crystal of $B$. thuringiensis isolates. A: B. thuringiensis S11; B: B. thuringiensis C55; C: B. thuringiensis J9; D: B. thuringiensis J145. 
expressed insecticidal activities in Diptera were G53, S2, S6, S11, S43 and C55, which were a total of 6 in number and those strains that expressed insecticidal activities in both Lepidoptera and Diptera were J9, J102, J114, J131, J145, J186 and J191, which were a total of 7 in number. Among the 13 isolated B. thuringiensis strains, strains S11 and C55 showed at least 90\% insecticidal activities in both of two species, L. ingenua and A. albopictus, and strain C55 showed at least 50\% insecticidal activities in B. agrestis. Strains J9 and J145 showed at least 70\% insecticidal activities in all three species of diamondback moth (P. xylostella), S. exigua, and S. litura, which are Lepidopteran insect pests while showing high insecticidal activities of at least $90 \%$ in A. albopictus, which is a Diptera insect pest (Table 4).

Based on the results of biological activity tests, four strains, strains S11, C55, J9 and J145 were selected and their $\mathrm{LC}_{50}$ and $\mathrm{LC}_{95}$ values were compared with those of B. thuringiensis subsp. israelensis strain CAB199, which is known to have high insecticidal activities in the Diptera insect pest mosquito (Table 5). As a result, strain the S11 showed the highest insecticidal activities with an $\mathrm{LC}_{50}$ value of $1.14 \times 10^{4}$ in $L$. ingenua larvae while the comparison strain CAB199 showed the highest $\mathrm{LC}_{50}$ value of $1.2 \times 10^{6}$ in $B$. agrestis larvae. As for the $\mathrm{LC}_{50}$ values in $A$. albopictus larvae, the comparison strain CAB199 showed the highest insecticidal activities with an $\mathrm{LC}_{50}$ value of $1.37 \times 10^{4}$. The $\mathrm{LC}_{95}$ values were

Table 3. Number of insecticidal B. thuring-

\begin{tabular}{cc} 
iensis & \\
\hline Crystal type & $\begin{array}{c}\text { Number of insecticidal } \\
\text { B. thuringiensis }\end{array}$ \\
\hline Bipyramidal & 8 \\
Spherical & 5 \\
\hline Total & 13 \\
\hline
\end{tabular}

Table 5. Toxicity of B. thuringiensis S11, C55 isolates against Diptera

\begin{tabular}{clcc}
\hline Tested larvae & strains & $\mathrm{LC}_{50}(\mathrm{cfu} / \mathrm{ml})$ & $\mathrm{LC}_{95}(\mathrm{cfu} / \mathrm{ml})$ \\
\hline \multirow{2}{*}{ L. ingenua } & $\mathrm{S} 11$ & $1.14 \times 10^{4}$ & $2.73 \times 10^{7}$ \\
& $\mathrm{C} 55$ & $1.88 \times 10^{5}$ & $5.14 \times 10^{7}$ \\
& $\mathrm{CAB} 199$ & $7.92 \times 10^{6}$ & $2.28 \times 10^{9}$ \\
\hline \multirow{3}{*}{ B. arestis } & $\mathrm{S} 11$ & $1.28 \times 10^{8}$ & $2.8 \times 10^{9}$ \\
& $\mathrm{C} 55$ & $3.77 \times 10^{6}$ & $1.75 \times 10^{10}$ \\
& $\mathrm{CAB} 199$ & $1.27 \times 10^{6}$ & $1.26 \times 10^{9}$ \\
\hline \multirow{5}{*}{ A. albopictus } & $\mathrm{S} 11$ & $4.36 \times 10^{6}$ & $1.99 \times 10^{8}$ \\
& $\mathrm{C} 55$ & $9.00 \times 10^{5}$ & $1.8 \times 10^{7}$ \\
& $\mathrm{~J} 145$ & $1.5 \times 10^{5}$ & $3.4 \times 10^{6}$ \\
& $\mathrm{CAB} 199$ & $1.37 \times 10^{4}$ & $4.37 \times 10^{5}$ \\
\hline
\end{tabular}

calculated and in the results, as with $\mathrm{LC}_{50}$ values, strain $\mathrm{S} 11$ showed the highest $\mathrm{LC}_{95}$ value indicating the highest insecticidal activities in L. ingenua larvae and the comparison strain CAB199 showed the highest insecticidal activities in two Diptera insect pest species, B. agrestis larvae and $A$. albopictus larvae.

Based on the results of the tests of the strains' insect pest lethal concentrations in Diptera, strain S11 were found to have high toxicity to the Diptera insect pest $L$. ingenua, indicating potential as a biological control agent.

\section{SDS-PAGE}

The $\delta$-endotoxin protein patterns of strains S11, C55, J9 and J145 that showed high insecticidal activities on Diptera insect pests in bioactivity tests were checked through SDS-PAGE. Electrophoresis was conducted and according to the results, strain S11 that showed

Table 4. Insecticidal activities of isolated B. thuringiensis against Lepidopteran and Dipteran larva

\begin{tabular}{|c|c|c|c|c|c|c|c|}
\hline \multirow{3}{*}{\multicolumn{2}{|c|}{ Tested larvae }} & \multicolumn{3}{|c|}{ Lepidopteran } & \multicolumn{3}{|c|}{ Dipteran } \\
\hline & & \multirow{2}{*}{$\frac{\text { Yponomenutidae }}{\text { P. xylostella }}$} & \multicolumn{2}{|c|}{ Noctuidae } & \multicolumn{2}{|c|}{ Sciaridae } & \multirow{2}{*}{$\frac{\text { Culicidae }}{\text { A. albopictus }}$} \\
\hline & & & S. exigua & S. litura & L. ingeaus & B. arestis & \\
\hline \multirow{13}{*}{ Isolates } & G53 & - & - & - & + & - & - \\
\hline & S2 & - & - & - & +++ & - & + \\
\hline & S6 & - & - & - & ++ & - & - \\
\hline & $\mathrm{S} 11$ & - & - & - & +++ & - & +++ \\
\hline & $\mathrm{S} 43$ & - & - & - & +++ & - & ++ \\
\hline & C55 & - & - & - & +++ & + & +++ \\
\hline & J9 & +++ & +++ & +++ & - & - & +++ \\
\hline & J102 & +++ & +++ & +++ & - & - & ++ \\
\hline & J114 & +++ & +++ & ++ & - & - & ++ \\
\hline & J131 & +++ & +++ & - & - & - & + \\
\hline & J145 & +++ & +++ & +++ & - & - & +++ \\
\hline & J186 & +++ & +++ & +++ & - & - & ++ \\
\hline & J191 & +++ & + & - & - & - & +++ \\
\hline
\end{tabular}

+++: Highly effective, >90\% lethality, ++: Effective, 70 89\% lethality, +: Low effective, 50 69\% lethality, -: not effective, $0 \sim 49 \%$ lethality. 
insecticidal activity only in the Diptera insect pests showed three bands, at $150 \mathrm{kDa}, 75 \mathrm{kDa}$ and $65 \mathrm{kDa}$, and strain C55 showed three main bands, at $150 \mathrm{kDa}, 70 \mathrm{kDa}$ and $25 \mathrm{kDa}$ (Fig. 3). The comparison strain, B. thuringiensis subsp. israelensis strain CAB199 showed bands at $130 \mathrm{kDa}, 70 \mathrm{kDa}, 28 \mathrm{kDa}$ and $22 \mathrm{kDa}$ thereby showing differences from the two strains. In order to identify the active toxins of strains S11 and C55, the parasporal inclusions of the two strains were made to react with $L$. ingenua triturated solution and electrophoresis was performed. As a result, the $150 \mathrm{kDa}$ band of strain S11 in was decomposed by the $L$. ingenua triturated solution so that bands were identified at $50 \mathrm{kDa}$ and $25 \mathrm{kDa}$ (Fig. 4) and the $150 \mathrm{kDa}$ and $75 \mathrm{kDa}$ bands of strain C55

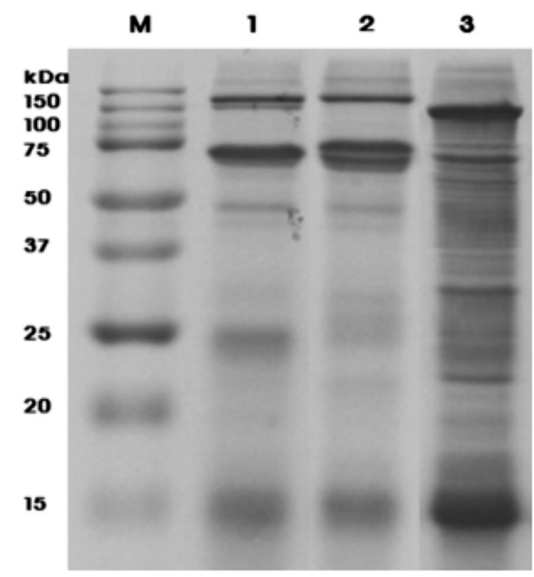

Fig. 3. SDS-PAGE analysis of parasporal inclusion of $B$. thuringiensis C55, S11, and CAB199. M: Standard marker; lane 1: B. thuringiensis C55; lane 2: B. thuringiensis S11; lane 3: B. thuringiensis subsp. israelensis CAB199.

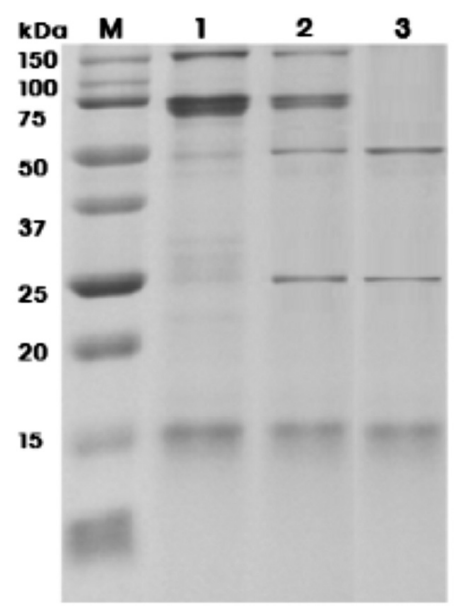

Fig. 4. SDS-PAGE analysis of $B$. thuringiensis S11. M: Standard marker; lane 1: $B$. thuringiensis S11; lane 2: $B$. thuringiensis $\mathrm{S} 11$ digested with larval homogenate for 15min; lane 3: B. thuringiensis S11 digested with larval homogenate for $30 \mathrm{~min}$. strain were decomposed by the $L$. ingenua triturated solution so that a band was shown at $60 \mathrm{kDa}, 45 \mathrm{kDa}$, $40 \mathrm{kDa}$, and $25 \mathrm{kDa}$ (Fig. 5).

In the case of strains J9 and J145, which exhibited insecticidal activities in Diptera as well as in Lepidoptera, a band about $130 \mathrm{kDa}$ was identified identically to B. thuringiensis subsp. aizawai strain KB098, which is known to show insecticidal activities in Lepidoptera and Diptera. To identify the active toxins of the three strains, the parasporal inclusions of the two strains were made to react with $L$. ingenua mid-gut

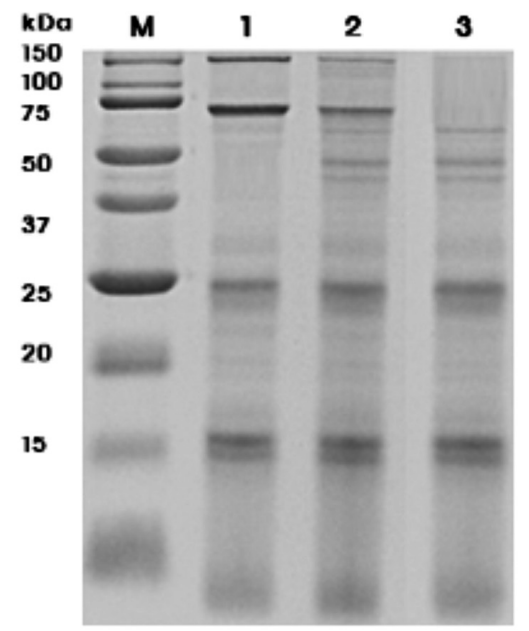

Fig. 5. SDS-PAGE analysis of $B$. thuringiensis C55. M: Standard marker; lane 1: B. thuringiensis C55; lane 2: B. thuringiensis C55 digested with larval homogenate for $15 \mathrm{~min}$; lane 3 : $B$. thuringiensis $\mathrm{C} 55$ digested with larval homogenate for $30 \mathrm{~min}$.

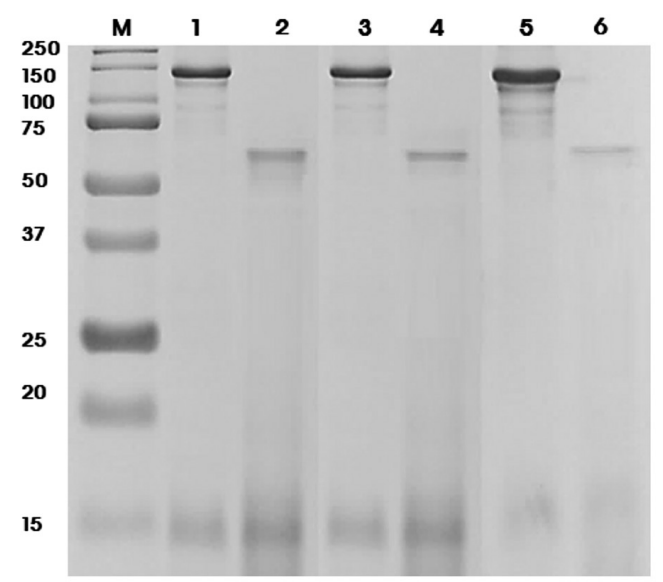

Fig. 6. SDS-PAGE analysis of parasporal inclusion of B. thuringiensis subsp. aizawai KB098, J9, and J145. M: Standard marker; lane 1: $B$. thuringiensis subsp. aizawai KB098; lane 2: B. thuringiensis subsp. aizawai KB098 digested with larval homogenate for $30 \mathrm{~min}$; lane 3: B. thuringiensis J9; lane 4: $B$. thuringiensis J9 digested with larval homogenate for $30 \mathrm{~min}$; lane $5: B$. thuringiensis J145; lane 6: B. thuringiensis J145 digested with larval homogenate for $30 \mathrm{~min}$. 
fluid and electrophoresis was performed. As a result, the total toxin at $130 \mathrm{kDa}$ of the three strains were decomposed and toxin bands with insecticidal activities in the Diptera could be identified at about $60-65 \mathrm{kDa}$. The sizes of $\delta$-endotoxin proteins and the active toxin band patterns after the reaction with $S$. exigua mid-gut fluid were shown to be similar in all of the three strains and it can be expected that strains J9 and J145 are $B$. thuringiensis subsp. aizawai strains (Fig. 6).

\section{Cry-type gene identification}

Strains S11 and C55, which showed insecticidal activities in at least two species of Diptera insect pests, were selected and the cry genes of those strains were analyzed. The representative cry genes with insecticidal activities in Diptera were reported as a total of 15 cry genes, which are cry1Aa, cry1Bc, cry2A, cry4Aa, cry4Ba, cry10Aa, cry11Aa, cry11Ba, cry19A, cry20A, cry24C, cry30A, cyt1Aa, cyt2Aa, and cyt2Ba including a total of
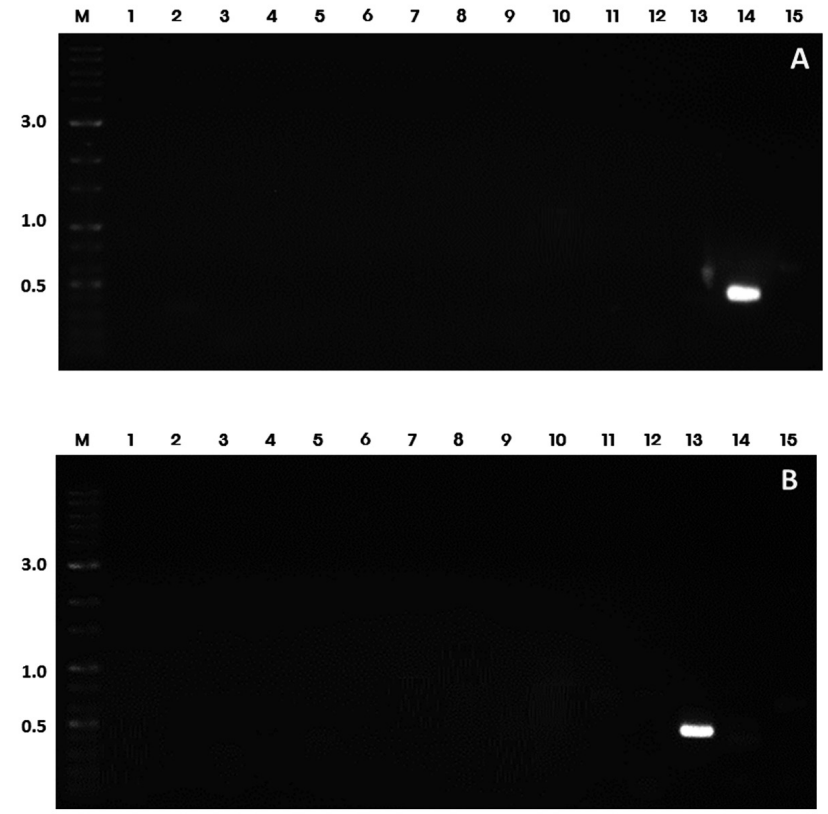

Fig. 7. Agarose gel (1\%) electrophoresis of PCR products obtained with specific primers for the cry genes.

A: B. thuringiensis S11. M: 100 bp DNA ladder marker; lane 1: cry $1 \mathrm{Aa}$, lane 2 : cry $1 \mathrm{Bc}$; lane 3 : cry $2 \mathrm{~A}$; lane 4 : cry 4Aa; lane 5: cry 4Ba; lane 6: cry 10Aa; lane 7: cry 11Aa; lane 8: cry 11Ba; lane 9: cry 19A; lane 10: cry 20A; lane 11: cry 24C, lane 12: cry 30A; lane 13: cyt 1Aa; lane 14: cyt 2Aa; lane 15: cyt $2 \mathrm{Ba}$.

B: B. thuringiensis C55. M: 100 bp DNA ladder marker; lane 1: cry $1 \mathrm{Aa}$, lane 2 : cry $1 \mathrm{Bc}$; lane 3 : cry $2 \mathrm{~A}$; lane 4 : cry 4A; lane 5: cry 4Ba; lane 6: cry 10Aa; lane 7: cry $11 \mathrm{Aa}$; lane 8: cry 11Ba; lane 9: cry 19A; lane 10: cry 20A; lane 11: cry 24C, lane 12: cry 30A; lane 13: cyt 2Aa; lane 14: cyt 1Aa; lane 15: cyt $2 \mathrm{Ba}$. six possessed by $B$. thuringiensis subsp. israelensis, which are cry4Aa, cry4Ba, cry10Aa, cry11Aa, cyt1Aa, cyt2Ba, and cyt2Aa (Van Frankenhuyzen, 2009). To analyze the cry genes possessed by the isolated $B$. thuringiensis strains S11 and C55, the representative 15 cry gene primers with insecticidal activities in Diptera were used to check the presence of each gene.

As a result, a band of $494 \mathrm{bp}$ size appeared in strains S11 and C55 indicating that these strains have cyt2A gene, which was not consistent with other cry genes possessed by B. thuringiensis subsp. israelensis, and no other gene appeared except for cyt2Aa (Fig. 7A and 7B). This result can be expected that there are unknown cry genes for having activities in Diptera except the tested cry genes (Table 6).

\section{Plasmid DNA analysis}

The cry genes of $B$. thuringiensis are involved in the formation of the size, shape, and activity of $\delta$-endotoxin proteins and are present on the plasmid DNA. The sizes and numbers of Plasmid DNAs vary from strain to strain even among strains in the same subspecies so that they can be important data that can be used to obtain information regarding the cry genes that encode endotoxins (McDowell and Mann, 1991, Sarrafzadah et al., 2007, Loeza-Laraa et al., 2005).

The Plasmid DNAs of the selected strains S11 and C55 were extracted and electrophoresed. As a result, strain S11 showed a total six bands, three above

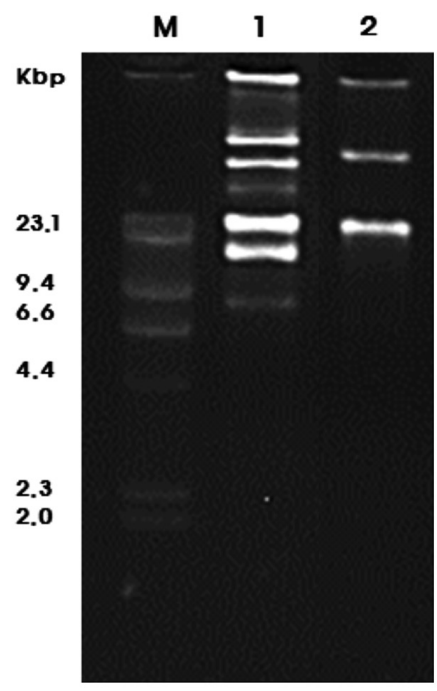

Fig. 8. Plasmid DNA patterns of $B$. thuringiensis isolates. M: Lamda DNA HindIII marker; lane 1: $B$. thuringiensis $\mathrm{S} 11$; lane 2: B. thuringiensis C55.

Table 6. Profiles of cry genes in B. thuringiensis strains

\begin{tabular}{cc}
\hline Strains & cry genes \\
\hline B. thuringiensis $\mathrm{S} 11$ & cyt2Aa \\
B. thuringiensis $\mathrm{C} 55$ & cyt2Aa \\
B. thuringiensis subsp. israelensis & cry4Aa, cry4Ba, cry10Aa, cry11Aa, cyt1Aa, cyt2Ba
\end{tabular}


23.1 Kbp and three below 23.1 Kbp. Strain C55 showed a total of two bands, one above $23.1 \mathrm{Kbp}$ and one below 23.1 Kbp (Fig. 8).

From the findings of this study, it was identified that strains S11 and C55 were different from the comparison strain B. thuringiensis subsp. israelensis with excellent insecticidal activities in Diptera insect pests in morphological characteristics, $\delta$-endotoxin protein characteristics, and plasmid DNA patterns and differences were identified between $B$. thuringiensis strains S11 and $\mathrm{C} 55$ too. Based on the above results, genetic studies on B. thuringiensis strains S11and C55 that show insecticidal effects on Diptera and studies on their potential as microbial insecticides should be continued.

\section{AUTHOR CONTRIBUTIONS}

Young A Hur designed the study, performed the comprehensive experiments, analyzed the data and wrote the paper. You Kyoung Lee participated in the pest control experiments. Hee Ji Kim performed the isolation of B. thuringiensis strains. Young Nam Youn edited the paper. Chisa Yasunaga-Aoki participated in the design of the study and discussed on the experiments and the results. Yong Man Yu supervised the work and wrote the paper. All authors assisted in editing of the manuscript and approved the final version.

\section{ACKNOWLEDGEMENTS}

The present study was conducted with the Chungnam National University's own research fund and these researchers thank for the grant of the research fund.

\section{REFERENCES}

Abdel-Hameed, A., G. Carlberg and O. M. El-Tayeb 1990 Studies on Bacillus thuringiensis $\mathrm{H}-14$ strains isolated in Egypt-III Selection of media for $\delta$-endotoxin production. World $J$. Microbiol. and Biotechnol., 6: 313-317

Argôlo-Filho, R. C and L. L. Loguercio 2013 Bacillus thuringiensis is an environmental pathogen and host-specificity has developed as an adaptation to human-generated ecological niches. Insects., 5: 62-91

Armengol, G., M. C. Escobar, M. E. Maldonado and S. Orduz 2007 Diversity of Colombian strains of Bacillus thuringiensis with insecticidal activity against Dipteran and Lepidopteran insects. J. appl. Microbial., 102: 77-88

Balaraman, K., S. L. Hoti and L. M. Manonmani 1981 Indigenous virulent strain of Bacillus thuringiensis, highly pathogenic and specific to mosquitoes. Curr. Sci., 50: 199-200

Bravo, A., S. Sarabia, L. Lopez, H. Ontiveros, C. Abarca, A. Ortiz and M. E. Nuñez-Valdez 1998 Characterization of cry genes in a Mexican Bacillus thuringiensis strain collection. J. Appl. Environ. Microbiol., 64: 4965-4972

Chambers, R. J., E. M. Wright and R. J. Lind 1993 Biological control of glasshouse sciarid flies (Bradysia spp.) with the predatory mite, Hypoaspis miles on cyclamen and poinsettia. Biocontrol Sci. Technol., 3: 285-293

Cloyd, R. A. 2000 Fungus gnat and shore fly management strategies: Panel discussion. In Proceedings of the 16th Conferences Insect and Disease Management Ornamentals, Society of American Florists, Alexandria, VA, USA, pp. 19-21

El Khoury, M., H. Azzouz, A. Chavanieu, N. Abdelmalak, J.
Chopineau and M. K. Awad, 2014 Isolation and characterization of a new Bacillus thuringiensis strain Lip harboring a new cry1Aa gene highly toxic to Ephestia kuehniella (Lepidoptera: Pyralidae) larvae. Arch Clin Microbiol., 196: 435-444

Erler, F., E. Polat, H. Demir, M. Catal and G. Tuna 2011 Control of mushroom sciarid fly Lycoriella ingenua populations with insect growth regulators applied by soil drench. J. Econ. Entomol., 104: 839-844

Finney, D. J. 1971 Probit Analysis, Estimation of the median effective dose. London: Cambridge University Press, pp. 333

Goldberg, L. J. and J. Margalit 1997 A bacterial spore demonstrating rapid larvicidal activity against Anopheles sergentii, Uranotaenia unguidultata, Culex univittatus, Aedes aegypti and Culex pipiens. Mosquito News 37: 246-251

Ishii, T. and M. Ohba 1993 Diversity of Bacillus thuringiensis environmental isolates showing larvicidal activity specific for mosquitoes. Microbiol., 139: 2849-2854

Jagdale, G. B., M. L. Casey, L. Cañas and P. S. Grewal 2007 Effect of entomopathogenic nematode species, split application and potting medium on the control of the fungus gnat, Bradysia difformis (Diptera: Sciaridae), in the greenhouse at alternating cold and warm temperatures. Biol. Control., 43: 23-30

Jeon, H. Y., J. A. Jung, T. J. Kang, C. Y. Yang and H. H. Kim 2007 Damage Status of Poinsettia by the Fungus Gnat (Bradysia difformis) and Its control with Predatory Mite (Hypoaspis aculeifer). Kor. J. Hort. Sci. Technol., 25: 468-473

Jin, N. Y., S. Y. Jung, C. Park, S. K. Paek, M. J. Seo, Y. N. Youn and Y. M. Yu 2009 The synergy effects of mixed treatment with tannic acid and Bacillus thuringiensis subsp. kurstaki KB100 against Spodoptera exigua (Lepidoptera: Noctuidae). J. Asia Pac. Entomol., 48: 519-526

KCPA, 2017 Agrochemicals use guide book. Korea crop protection association

Kim, H. H., M. R. Cho, T. J. Kang, S. J. Ahn, S. W. Jeon, C. J. Lee and J. C. Cheong 2012 Damage and biological control of dark winged fungus gnats, Lycoriella ingenua (Diptera: Sciaridae) in a shiitake cultivation. J. Mushrooms., 10: 184-190

Kim, H. S., D. W. Lee, H. W. Park, S. K. Kang, Y. M. Yu and J. I. Kim 1995 Distribution and characterization of Bacillus thuringiensis isolated from soils of sericultural farms in Korea. Kor. J. Sericult. Sci., 37: 57-61

Laemmli, U. K. 1970 Cleavage of structural proteins during the assembly of the head of bacteriophage T4. Nature., 227: 680685

Lee, B. J., M. Lee, Y. G. Kim, K. W. Lee, B. E. Lee and G. S. Seo 2015a Damages and Developmental Characteristics of Fungus Gnat, Lycoriella ingenua (Diptera: Sciaridae) in Button Mushroom Cultivation. J. Murshrooms., 13: 145-150

Lee, Y. K., N. Y. Jin, B. R. Lee, M. J. Seo, Y. N. Youn, C. YasunagaAoki and Y. M. Yu 2015b Isolation and characterization of new Bacillus thuringiensis strains with insecticidal activity for difficult to control lepidopteran pests. J. Fac. Agr. Kyushu Univ., 60: $103-112$

Li, H. and G. Bouwer 2014 Evaluation of the synergistic activities of Bacillus thuringiensis Cry proteins against Helicoverpa armigera (Lepidoptera: Noctuidae). J. Invertebr. Pathol., 121: $7-13$

Loeza-Lara, P. D., G. Benintende, J. Cozzi, A. Ochoa-Zarzosa, V. M. Baizabal-Aguirre, J. J. Valdez-Alarcón and J. E. López-Meza 2005 The plasmid pBMBt1 from Bacillus thuringiensis subsp. darmstadiensis (INTA Mo14-4) replicates by the rolling-circle mechanism and encodes a novel insecticidal crystal protein-like gene. Plasmid, 54: 229-240

McDowell, D. G. and N. H. Mann 1991 Characterization and sequence analysis of a small plasmid from Bacillus thuringiensis var. kurstaki strain HD1-DIPEL. Plasmid, 25: 113-120

Ohba, M. and K. Aizawa 1978 Serological identification of Bacillus thuringiensis and related bacteria isolated in Japan. J. Invertebr. Pathol., 32: 303-309

Orduz, S., W. Rojas, M. M. Correa, A. E. Montoya and H. Barjac 1992 A new serotype of Bacillus thuringiensis from Colombia toxic to mosquito larvae. J. Invertebr. Pathol., 99-103 
Padua, L. E., M. Ohba and K. Aizawa 1984 Isolation of a Bacillus thuringiensis strain (serotype 8a: 8b) highly and selectively toxic against mosquito larvae. J. Invertebr. Pathol., 44: 12-17

Quesada-Moraga, E., E. García-Tóvar, P. Valverde-Garcıa and C. Santiago-Alvarez 2004 Isolation, geographical diversity and insecticidal activity of Bacillus thuringiensis from soils in Spain. Microbiol. Res. J. Int., 159: 59-71

Raymond, M. 1985 Presentation d'un programme basic d'analyse log-probit pour micro-ordinateur. Cah. ORSTOM Ser. Entomo. Med. Parasitol., 23: 117-121

Sarrafzadeh, M. H., F. Bigey, B. Capariccio, M. R. Mehrnia, J. P. Guiraud and J. M. Navarro 2007 Simple indicators of plasmid loss during fermentation of Bacillus thuringiensis. Enzyme Microb. Technol., 40: 1052-1058

Shamshad, A. 2010 The development of integrated pest management for the control of mushroom sciarid flies, Lycoriella ingenua (Dufour) and Bradysia ocellaris (Comstock), in cultivated mushrooms. J. Pest Sci., 66: 1063-1074

Shim, J. C., Y.H. Yoon, K. N. Yeon, S. B. Shim and H. S. Yu 1990 Isolation of Bacillus thuringiensis from soil and control effect of medically important insects. J. Asia Pac. Entomol., 20: 179188

Tabashnik, B. E., N. L. Cushing, N. Finson and M. W. Johnson 1990 Field development resistance to Bacillus thuringiensis in diamondback moth (Lepidoptera: Plutellidae). J. Econ. Entomol., 83: 1671-1676

Van Frankenhuyzen, K. 2009 Insecticidal activity of Bacillus thuringiensis crystal proteins. J. Invertebr. Pathol., 101: $1-16$

Vaughan, M. M., D. Tholl and J. G. Tokuhisa 2011 An aeroponic culture system for the study of root herbivory on Arabidopsis thaliana. Plant Methods., 7: 5

WHO 2005 Guidelines for laboratory and field testing of mosquito larvicides. World Health Organization., 13: 3-36

Yoon, J. B., H. H. Kim, C. R. Jung, M. G. Kang, S. J. Kwon, D. H. Kim and M. H. Seo 2016 Molecular identification of the dominant species of dark-winged fungus gnat (Diptera: Sciaridae) from button mushroom (Agaricus bisporus) in Korea. J. Asia Pac. Entomol., 55: 471-475 